\title{
The practicalities and barriers of using TEG6s in code red traumas: an observational study in one London major trauma centre
}

\author{
Sarah Morton, MBBS MRCP*; Judi Galea, $\mathrm{MBChB}^{*}$; James Uprichard, $\mathrm{PhD}^{\dagger}$; Anthony Hudson, $\mathrm{MB}, \mathrm{BCh}^{*}$
}

\begin{abstract}
CLINICIAN'S CAPSULE
What is known about the topic?

Thromboelastography (TEG) can identify trauma-induced coagulopathy and guide blood product management.

What did this study ask?

What currently limits the utilization of TEG in one major trauma centre, and can it be used practically?

What did this study find?

TEG can be successfully run during a major trauma, but a lack of knowledge relating to interpretation hinders its impact on blood component management.

Why does this study matter to clinicians?

Prior to introducing point-of-care tests, e.g., TEG, education of staff is required to ensure it is optimally utilized.
\end{abstract}

\section{ABSTRACT}

Objective: Trauma induced coagulopathy is a disorder of the coagulation pathway that occurs following major trauma. "Code red trauma" require massive hemorrhage protocol activation. The aim was to qualitatively establish the reasons TEG is not currently utilized and the ongoing practicalities in performing a TEG sample for trauma-related massive hemorrhage.

Methods: A pilot study was performed using a TEG6s machine within one central London Major Trauma Centre's resuscitation department. Staff were asked to run a TEG sample on any "code red" patient who attended during the trial. Staff were given questionnaires both before and after the trial to assess the knowledge around TEG.

Results: A TEG sample was performed in $75 \%$ of the sixteen "code red traumas," with one sample being unsuccessful. Only one patient had their blood component management altered due to the TEG result with only $50 \%$ of consultants and registrars surveyed feeling confident in interpreting TEG results.
Conclusion: TEG6s samples can be run within the resuscitation department in a "code red trauma." However, there is a significant lack of knowledge relating to TEG within the emergency department which is likely to hinder its impact on personalized blood component management. More research is required in how to provide appropriate education in a busy setting to enable TEG to be utilized appropriately.

\section{RÉSUMÉ}

Objectif: La coagulopathie post-traumatique est un trouble de I'hémostase, consécutif à un trauma grave. Le déclenchement du " code rouge " dans les cas de trauma nécessite la mise en branle du protocole de traitement des hémorragies massives. L'étude avait donc pour but de cerner, sur le plan de la qualité, les raisons pour lesquelles la thomboélastographie (TEG) ne s'utilise pas de nos jours ainsi que les aspects pratiques courants de cet examen dans les cas d'hémorragie massive post-traumatique.

Méthode: II s'agit d'une étude pilote menée, à l'aide de I'analyseur TEG 6s, en salle de réanimation, dans un grand centre de traumatologie à Londres. On a demandé au personnel d'effectuer une TEG chez les patients ayant fait l'objet d'un " code rouge " durant la période d'étude. Les membres du personnel ont rempli un questionnaire avant et après l'étude afin que soient évaluées leurs connaissances sur la TEG.

Résultats: Une TEG a été effectuée dans $75 \%$ des 16 cas de déclenchement du " code rouge " consécutif à un trauma, et toutes ont abouti sauf une. L'administration de composants sanguins a été modifiée chez un seul patient par suite des résultats de la TEG, et $50 \%$ seulement des consultants et des registrars (résidents au R.-U.) ayant participé à l'étude se sentaient suffisamment à l'aise pour interpréter les résultats de la TEG.

Conclusion: Les analyseurs TEG 6s peuvent s'utiliser en salle de réanimation, dans les cas de " code rouge " consécutif à un trauma, mais le personnel du service des urgences souffre

From the *St George's Hospital, Blackshaw Road, London, the United Kingdom; and the Centre for Haemostasis and Thrombosis, St George's University Hospitals NHS Foundation Trust, London, the United Kingdom.

Correspondence to: Dr. Anthony Hudson, St George's Hospital, Blackshaw Road, London, UK SW17 00T; Email: Anthony.Hudson@stgeorges. nhs.uk 
d'un manque important de connaissances sur la TEG, ce qui a sans doute pour effet de freiner la personnalisation de l'administration des composants sanguins. II faudrait donc mener d'autres études afin de déterminer la meilleure manière de donner une formation appropriée à un personnel déjà affairé sur la bonne utilisation de la TEG.

Keywords: coagulopathy, TEG, trauma

\section{BACKGROUND}

Trauma-induced coagulopathy (TIC) is a disorder of the coagulation pathway that occurs following a major trauma and associated with increased mortality and morbidity. ${ }^{1}$ Thromboelastography (TEG) is one method of assessing for TIC. Studies have suggested that TEG can identify TIC and may be useful for predicting blood component transfusion. ${ }^{2-4}$ TEG6s (Haemonetics ${ }^{\circledR}$ ) is a cartridge-based system that the company claims is more reproducible than previous models were.

Trauma resuscitations, normally activated by the ambulance service as per its guidelines, within St. George's Hospital are led by emergency department (ED) consultants or registrars as the trauma team leader (TTL). If a major hemorrhage is suspected, either on arrival at the hospital or pre-hospital, a "code red" trauma is activated, allowing immediate access to blood products; the TTL guides any blood components that are transfused according to the TTL request. The kaolin-activated TEG assay, included in the hospital guidelines, uses the TEG 5000 machines (Haemonetics ${ }^{\circledR}$ ) situated in the intensive care unit (ICU) and is rarely performed. The ED staff's understanding and knowledge of TIC and TEG is unclear.

This study aimed to establish qualitatively the reasons why TEG is not currently utilized and the ongoing practicalities in performing a TEG sample within the resuscitation room of an $\mathrm{ED}$ of one London major trauma centre.

\section{METHODS}

This pilot study was carried out at one London major trauma centre. A trial period was arranged for a TEG6s to be placed within the resuscitation room to assess utilization of TEG; there was no obligation to purchase.

All ED staff were made aware of the TEG6s, with demonstrations on its use at the start of the trial. Staff were encouraged to run a TEG sample on any code red patient who attended during the trial period (December
2016 through January 2017 inclusive). The results were available to the TTLs to use as they felt appropriate (as would have been the case if a TEG sample had been run elsewhere).

Prior to the introduction of the TEG machine, a questionnaire was distributed by hand to doctors and nurses within the ED to establish current knowledge around TEG. The questionnaire was distributed over the course of several days by one author to ensure suitable representation by ED staff (approximately 50\% of staff employed in the ED at that time). Following the trial, all staff who had run a TEG sample during the trial were contacted for their feedback using an online questionnaire (contact details were recorded at the time of running the TEG). A second questionnaire was distributed within the ED asking for wider staff opinion on the use of TEG in the same manner as the initial questionnaire; staff initially surveyed were re-surveyed, if possible (questionnaires in Appendix 1).

Ethical approval was not required, as there was no change in current practice or the established code red protocol (Appendix 2). ${ }^{5}$ Data were recorded and analyzed using Microsoft Excel 2016 and handled according to information governance regulations.

\section{RESULTS}

During the trial, there were 16 code red activations. A TEG sample was performed for $75 \%$ of the cases, with one sample being unsuccessful $(69 \%$ success rate overall; Appendix 3). The results relating to pre-trial TEG awareness are demonstrated in Table 1. Of the five members of staff who utilized a TEG6s during the trial, all managed to perform the TEG6s successfully and stated that they found it easy to use (one person who ran a TEG6s could not be contacted; this was related to the unsuccessful sample). Blood components for one patient were prescribed based on the TEG result. Following the trial period, the results relating to the TEG machine and knowledge surrounding it in the ED are shown in Table 1. 


\begin{tabular}{|c|c|c|c|c|c|c|c|c|}
\hline Staff role & $\begin{array}{l}\text { Number } \\
\text { of staff } \\
\text { pre-trial }\end{array}$ & $\begin{array}{l}\text { Number } \\
\text { who had } \\
\text { heard of } \\
\text { TIC pre- } \\
\text { trial }\end{array}$ & $\begin{array}{l}\text { Number } \\
\text { who } \\
\text { understand } \\
\text { what TIC } \\
\text { was pre- } \\
\text { trial }\end{array}$ & $\begin{array}{l}\text { Number of } \\
\text { staff who } \\
\text { heard of } \\
\text { TEG pre- } \\
\text { trial }\end{array}$ & $\begin{array}{l}\text { Number } \\
\text { of staff } \\
\text { post-trial }\end{array}$ & $\begin{array}{l}\text { Number of staff } \\
\text { who felt TEG could } \\
\text { be utilized in the } \\
\text { resuscitation room } \\
\text { post-trial }\end{array}$ & $\begin{array}{l}\text { Number of staff } \\
\text { who felt } \\
\text { confident in } \\
\text { interpreting TEG } \\
\text { results post-trial }\end{array}$ & $\begin{array}{l}\text { Number of staff that felt TEG } \\
\text { results would guide blood } \\
\text { component management } \\
\text { based on their current } \\
\text { knowledge post-trial }\end{array}$ \\
\hline $\begin{array}{r}\text { Band } 5 \\
\text { nurse }\end{array}$ & 20 & 8 & 7 & 5 & 16 & 16 & 3 & 7 \\
\hline $\begin{array}{r}\text { Band } 6 \\
\text { nurse }\end{array}$ & 6 & 6 & 6 & 6 & 8 & 8 & 2 & 5 \\
\hline $\begin{array}{r}\text { Band } 7 \\
\text { nurse }\end{array}$ & 3 & 1 & 0 & 1 & 3 & 3 & 1 & 0 \\
\hline $\begin{array}{l}\text { Medical } \\
\text { assistant }\end{array}$ & 4 & 1 & 0 & 2 & 2 & 1 & 0 & 0 \\
\hline Matron & 1 & 1 & 1 & 0 & 0 & N/A & $N / A$ & N/A \\
\hline $\begin{array}{l}\text { Senior } \\
\text { house } \\
\text { officer* }\end{array}$ & 17 & 12 & 8 & 6 & 7 & 7 & 1 & 3 \\
\hline Registrar & 4 & 4 & 4 & 4 & 10 & 10 & 6 & 8 \\
\hline Consultant & 3 & 3 & 3 & 3 & 6 & 6 & 2 & 4 \\
\hline Total & 58 & $36(62 \%)$ & $29(50 \%)$ & $27(47 \%)$ & 52 & $51(98 \%)$ & $15(29 \%)$ & $27(52 \%)$ \\
\hline
\end{tabular}

\section{DISCUSSION}

This study demonstrated that it is possible to run TEG6s samples within an ED, but there is a lack of education regarding TIC and the interpretation of TEG results; this is an important barrier to TEG utilization and likely to hinder its impact on personalizing blood component management.

Only one patient had their blood component management altered because of the TEG result, as there was a lack of confidence amongst clinicians in interpreting the results; only eight of the 16 consultants and registrars surveyed felt confident in interpreting the TEG results. This is consistent with a study that found only $11 \%$ of doctors correctly estimated the number of patients with TIC. ${ }^{6}$ Our work is also similar to another investigation that concluded emergency physicians lack core knowledge on the use of blood and blood components in the context of major hemorrhage following trauma. ${ }^{7}$ Therefore, it would appear that more research into how best to educate staff on the use, value, and interpretation of TEG is required. Unless this is performed, we are unlikely to see TEG results being used to guide blood component transfusion as literature indicates it has the potential to do so. ${ }^{3,8}$

\section{LIMITATIONS}

This study was based at one London major trauma centre only and may not reflect the findings of other centres. However, the majority of doctors included have worked at other EDs in the United Kingdom and abroad, so the results may not be dissimilar to those of other centres. There was also only a limited number of staff who were required to run a TEG during the trial period that might have limited its generalisability; however, the same staff might have consistently run a TEG as a result of the trauma team protocol.

\section{CONCLUSION}

Viscoelastic haemostatic assays, in particular, TEG6s, are likely to be useful in guiding blood component support in a timely manner during the initial resuscitation phase of a trauma patient. However, considerable education is required to make practical use of the TEG result. Until knowledge regarding TEG and its interpretation becomes more widespread, then TEG, or indeed similar point-of-care testing, is unlikely to be utilized to benefit patients fully. 


\section{SUPPLEMENTARY MATERIAL}

To view supplementary material for this article, please visit https://doi.org/10.1017/cem.2018.426

Acknowledgements: Our thanks go to Haemonetics who lent the TEG6s machine to the department on a trial basis. The cartridges required for the TEG6s were donated by Haemotinics. All authors were involved in the development of this study and its design. SM undertook the literature search, writing, and critical revision of the manuscript. JG undertook data interpretation and critical revision. JG and JU were involved in data interpretation. $\mathrm{JU}$ and $\mathrm{AH}$ were involved in critical revisions of the manuscript.

Competing interests: Haemonetics did not have any involvement in the collection or analysis of this data.

\section{REFERENCES}

1. Brohi K, Singh J, Heron M, Coats T. Acute traumatic coagulopathy. 7 Trauma 2003;54(6):1127-30.

2. da Luz LT, Nascimento B, Rizoli S. Thromboelastography $\left(\mathrm{TEG}^{\circledR}\right)$ : practical considerations on its clinical use in trauma resuscitation. Scand 7 Trauma Resusc Emerg Med 2013:21:29.
3. Tapia NM, Chang A, Norman M, et al. TEG-guided resuscitation is superior to standardized MTP resuscitation in massively transfused penetrating trauma patients. 7 Trauma Acute Care Surg 2013;74(2):378-85.

4. Nystrup KB, Windelov NA, Thomsen AB, Johansson PI. Reduced clot strength upon admission, evaluated by thrombelastography (TEG), in trauma patients is independently associated with increased 30-day mortality. Scand 7 Trauma Resusc Emerg Med 2011; 19:52.

5. Health Research Authority. Is my study research? Medical Research Council; 2017 Available at: http://www.hra-deci siontools.org.uk/research/result7.html (accessed May 12, 2017).

6. Jeger V, Urwyler N, Zimmermann H, Exadaktylos AK. Trauma-induced coagulopathy in severely injured patients: knowledge lost in translation? Emerg Med 7 2010;27 (7):551-2.

7. Milligan C, Higginson I, Smith JE. Emergency department staff knowledge of massive transfusion for trauma: the need for an evidence based protocol. Emerg Med 7 2011; 28 (10):870-2.

8. Holcomb JB, Minei KM, Scerbo ML, et al. Admission rapid thrombelastography can replace conventional coagulation tests in the emergency department experience with 1974 consecutive trauma patients. Ann Surg 2012;256 (3):476-86. 